\title{
REVIEW
}

\section{Behavioural surveillance: the value of national coordination}

\section{A McGarrigle, K A Fenton, O N Gill, G Hughes, D Morgan, B Evans}

Behavioural surveillance programmes have enabled the description of population patterns of risk behaviours for STI and HIV transmission and aid in the understanding of how epidemics of STI are generated. They have been instrumental in helping to refine public health interventions and inform the targeting of sexual health promotion and disease control strategies. The formalisation and coordination of behavioural surveillance in England and Wales could optimise our ability to measure the impact of interventions and health promotion strategies on behaviour. This will be particularly useful for monitoring the progress towards specific disease control targets set in the Department of Health's new Sexual Health and HIV Strategy.

See end of article for authors' affiliations

...........................

Ms Christine McGarrigle HIV/STI Division, Public Health Laboratory Service, Communicable Disease Surveillance Centre, 61 Colindale Ave, London NW9 5EQ, UK; cmcgarri@phls.org.uk

Accepted for publication 5 August 2002
S exually transmitted infections (STI) and HIV result in considerable morbidity and mortality with substantial social and economic cost. ${ }^{1}$ They place considerable burden on healthcare resources required for their treatment and prevention as well as long term management required for their sequelae including ectopic pregnancy, cervical cancer, and infertility. STIs are important in their own right but may also be markers for risk of HIV. Teenagers and young adults, women, and some ethnic minority groups are disproportionately affected..$^{2-5}$ Sexual behaviour remains the key determinant of STI transmission. Thus, the key indicators for understanding and monitoring transmission rates need to be appropriate for the population and risk group under consideration.

There is evidence of deterioration in sexual health in the United Kingdom. Surveillance data indicate large recent increases in the numbers and rates of bacterial and viral STIs in the United Kingdom. In 2001 there were 673000 new episodes seen at genitourinary medicine (GUM) clinics in England. ${ }^{6}$ New diagnoses of STI between 1996 and 2001 rose by $86 \%$ for gonorrhoea, $501 \%$ for infectious syphilis, and by $106 \%$ for genital chlamydia. The highest numbers of HIV diagnoses were seen in 2001 and there is evidence to suggest that HIV transmission is not slowing. ${ }^{7}$ There have also been outbreaks of syphilis in homosexual men, many of whom have HIV. ${ }^{8}$ These rises have been attributed to increasing high risk sexual behaviour, including unprotected sex and high rates of partner change particularly in young heterosexuals ${ }^{10}{ }^{11}$ and men who have sex with men (MSM). ${ }^{8}{ }^{12}$ Data from the National Survey of Sexual Attitudes and Lifestyle (Natsal) confirm this. ${ }^{13}$ Similar increases have been seen in western ${ }^{14}$ and eastern Europe $^{1617}$ and the United States. ${ }^{18-20}$ The resurgence of acute STI, the emergence of STI outbreaks among MSM, and concomitant increases in the risk of HIV transmission are cause for concern.

HIV and STI surveillance data in the United Kingdom are useful for monitoring trends in diagnoses. However, they are relatively poor indicators of infection incidence and burden in the population as they are influenced by a number of factors including frequency of symptomatic disease, test sensitivity and uptake, health seeking behaviours, and referral patterns. These factors also limit their usefulness for measuring the success of prevention programmes. Several factors unrelated to prevention programmes can contribute to observed stabilisation or decrease in STI and HIV prevalence in a given setting. These can include mortality, saturation effects in subpopulations at higher risk, differential migration patterns, or sampling bias.

Although disease surveillance data suggest deterioration in sexual health in the United Kingdom since the mid-1990s, they do not provide information on the sexual behaviours or mixing patterns that may be underlying this trend. Public health surveillance of sexual behaviour is needed to measure risk behaviours that will both allow the monitoring of the effectiveness of prevention programmes and may provide early warning signs for the spread of HIV and STIs. This has been achieved in many other countries including some in Asia, ${ }^{21-23}$ Africa, ${ }^{24}$ Europe, ${ }^{25}$ and the United States. ${ }^{26}$ Trends over time are needed because while one-off studies can provide useful baseline information trends are necessary for interpretation. The outcome should be timely, relevant, and have high quality data, which can allow those in health promotion and disease prevention to respond effectively to observed changes. ${ }^{27}$

\section{WHAT IS BEHAVIOURAL SURVEILLANCE?}

Behavioural surveillance is the ongoing systematic collection, analysis, and interpretation of behavioural data relevant to understanding trends in the sexual transmission of infection. ${ }^{28}$ This should be followed by timely dissemination of these data to those responsible for prevention and control. Knowledge of the size of the population groups at risk, and the nature and determinants of risk within those populations are necessary. Behavioural surveillance generally aims to monitor trends in two broad groups of indicators; 
firstly, those that allow the identification of population subgroups at increased risk-for example, age, sex, sexual orientation, and ethnicity. Secondly, those behaviours that are amenable to change-for example, number and type of sexual partnerships, condom use, unprotected anal intercourse. The validity and reliability of sensitive data on behaviour are critical as they are self reported and can't be directly measured. ${ }^{29}$ The triangulation of a small set of core measures selected from surveillance data and other complementary sources can strengthen the interpretation of these data as the relation between sexual behaviour and STI transmission is complex.

Any attempt to establish behavioural surveillance in England and Wales should therefore seek to answer the following questions: which behaviours are important determinants of current STI and HIV transmission? How are these behaviours distributed and how can they be measured over time? What key behavioural data are not currently being collected? How best can these gaps be filled?

\section{HOW MAY IT BE ACHIEVED? \\ General population surveys}

Behavioural surveillance is generally conducted at two levels, among the general population and within targeted risk groups. General population surveys are useful in assessing overall trends and distribution of behaviours that may be associated with STI transmission. These provide the most robust estimates of prevalence of behaviours, as they largely avoid the biases inherent in most targeted population surveys. Although regular repeated surveys are needed to measure changes in behaviours over time their expense may make this difficult. Adding additional questions to existing population social surveys is a method that has been successfully deployed in other countries $^{30}$ as a cost effective way of getting population based estimates. This has been suggested for collecting sexual behaviour data in the United Kingdom. ${ }^{29} \mathrm{~A}$ large number of surveys are currently carried out which could be used in this way. ${ }^{31}{ }^{32}$ This kind of survey makes it possible to access a general population sample, but does limit the number of questions that can be asked.

General population surveys are usually less suitable for obtaining detailed information on population subgroups at highest risk. These groups tend to be small, more clustered, and difficult to access and small subgroups of individuals with relatively rare risk behaviours may not be captured in sufficient numbers. Groups of particular interest for HIV and STI transmission include homosexual and bisexual men, injecting drug users, commercial sex workers, and ethnic minorities, particularly those from or who have contact with countries with a high HIV/STI prevalence. These problems can be overcome through adapting study designs to include oversampling and focused enumeration. ${ }^{13}$

\section{Targeted population surveys}

Targeted population surveys are also a useful adjunct to these general population surveys as they give greater detail on populations at highest risk. However, the difficulty in accessing these populations makes probability sampling costly. More cost effective sampling strategies are needed; these can include advertising, snowballing, recruiting from GUM clinics, and social and commercial venues. However, these strategies may result in a sample selection bias and decreased representativeness of results. Targeted behavioural surveillance can include serial cross sectional surveys, using the same sampling strategy and using core questions to ascertain the prevalence of risk behaviours.

The disadvantage of targeted population surveys is that they are likely to be unrepresentative, given the nature of the convenience sampling. Those accessed through this mixture of social venues can only be representative of those using these sites. In addition, even among venue attenders the behaviour of study respondents may systematically differ from nonrespondents. In order to overcome this problem, surveys from a range of settings are needed, in order to achieve a more representative sample. New and innovative ways of accessing these populations are needed-for example, accessing MSM through internet chatrooms. ${ }^{33}$ Cross comparability of surveys done in different populations accessed through different means will allow an overview picture of the distribution of behavioural risk within the population under investigation. Questions that will allow the linking of the populations will enhance the interpretation of the individual surveys. ${ }^{35}$

\section{Behavioural surveillance in England and Wales: assessing the existing capacity \\ Disease surveillance}

Current surveillance systems collect limited data on the behavioural determinants of STI transmission. Where they exist they are often limited to facilitate ease of completion by busy clinical staff. Most systems rely on methods more focused on disease outcome, practicality, uniformity, and rapidity rather than on obtaining full demographic and behavioural details. Generally, the additional data collected are minimal (typically age, sex, sexual orientation) (table 1). These allow the grouping of diseases by risk factors, although clearly these are not behaviours amenable to change. Some enhanced surveillance systems have been developed that include more detailed behavioural data to allow the characterisation of those with diagnosed infections ${ }^{36}{ }^{37}$ (table 1) For example, the enhanced KC60 surveillance system will not only allow more risk factor information to be collected on an individual basis, but will also allow rates of co-infection and re-infection of STI to be examined and core groups to be more accurately described. ${ }^{38}$

There is comprehensive national surveillance of AIDS cases and diagnosed HIV infections. ${ }^{39-41}$ This surveillance system has recently been enhanced, and now clinicians are also asked to report all newly diagnosed HIV infections. The new clinician HIV and AIDS report form collects more behavioural data at the time of first HIV diagnosis (table 1) and provides the most comprehensive picture of all surveillance systems.

The unlinked anonymous HIV seroprevalence surveys provide sentinel HIV prevalence data and have been ongoing since $1990 .^{42}$ Limited demographic and behavioural data are collected with the unlinked residual specimens following clinical tests. The surveys cover both those at higher risk of infection, such as homosexual men and heterosexuals attending GUM clinics and injecting drug users attending services, and a more general population sample through monitoring HIV prevalence in over $60 \%$ of all pregnant women. The survey of injecting drug users differs in that a voluntary saliva sample is provided with a self completed questionnaire detailing demographic, sexual, and drug injecting behaviour. This survey represents some of the most detailed sexual behaviour data collected within the existing surveillance systems. ${ }^{43}$

Data from the National Blood Service (NBS) provide prevalence information in a lower risk population group, as the criteria for donation excludes those at increased risk of blood borne infections, including men who have had sex with men, those who have ever injected drugs, and those who have had heterosexual contact with high risk partners ${ }^{44}$ (table 1). Laboratory reports for confirmed acute hepatitis $\mathrm{B}$ are also routinely collected nationally. ${ }^{45}$

\section{BEHAVIOURAL SURVEYS}

Table 2 illustrates existing ongoing behavioural surveys carried out by different academic and research groups in Britain. Two general population surveys of adults are currently carried out. The first, Natsal, a probability sample study has been carried out twice a decade apart, ${ }^{13}{ }^{47}$ remains the largest probability sample study of its kind in Britain. The 2000 survey 


\begin{tabular}{|c|c|c|c|c|c|c|c|c|}
\hline Name and custodian & Description & $\begin{array}{l}\text { Geographical } \\
\text { area }\end{array}$ & Population covered & Time period & Demographic & Behavioural & Biological & Reference \\
\hline \multicolumn{9}{|c|}{ Sexually transmitted infection surveillance } \\
\hline $\begin{array}{l}\text { New episodes seen at } \\
\text { genitourinary medicine clinics } \\
\text { (KC60). CDSC }\end{array}$ & $\begin{array}{l}\text { Statutory reporting of all episodes } \\
\text { diagnosed at GUM clinics }\end{array}$ & National & $\begin{array}{l}\text { All episodes diagnosed at } \\
\text { GUM clinics }\end{array}$ & 1917- & Age group, sex & $\begin{array}{l}\text { Sexual orientation (selected } \\
\text { diagnoses) }\end{array}$ & STI diagnosis & 6 \\
\hline $\begin{array}{l}\text { Enhanced Surveillance of } \\
\text { sexually transmitted infections in } \\
\text { England. CDSC }\end{array}$ & $\begin{array}{l}\text { Individual based KC } 60 \text { by clinic, statutory } \\
\text { reporting }\end{array}$ & London & $\begin{array}{l}\text { All individuals attending } \\
\text { GUM clinics }\end{array}$ & 2000 & $\begin{array}{l}\text { Age, sex, ethnicity, } \\
\text { residence }\end{array}$ & $\begin{array}{l}\text { Sexual orientation, previous } \\
\text { STI, coinfections, repeat } \\
\text { infections }\end{array}$ & STI diagnoses & \\
\hline $\begin{array}{l}\text { Gonococcal resistance to } \\
\text { antimicrobials surveillance } \\
\text { programme (GRASP). CDSC }\end{array}$ & $\begin{array}{l}\text { Active, sentinel surveillance system prompted } \\
\text { by laboratory referrals of gonococcal } \\
\text { isolates to determine the epidemiology of } \\
\text { antimicrobial resistance in north. } \\
N \text { gonorrhoeae in England and Wales. } \\
\text { Sampling for } 3 \text { months of each year. }\end{array}$ & $\begin{array}{l}30 \text { GUM } \\
\text { clinics }\end{array}$ & $\begin{array}{l}\text { Individuals with antibiotic } \\
\text { resistant gonococcol } \\
\text { infections }\end{array}$ & $2000-3$ & $\begin{array}{l}\text { Age, sex, ethnicity, } \\
\text { residence }\end{array}$ & $\begin{array}{l}\text { Sexual orientation, number of } \\
\text { sexual partners, region of sex } \\
\text { abroad, concurrent STI, } \\
\text { previous gonorrhoea }\end{array}$ & $\begin{array}{l}\text { Gonorrhoea, } \\
\text { antibiotic } \\
\text { resistance, site of } \\
\text { infection }\end{array}$ & 37 \\
\hline $\begin{array}{l}\text { Routine laboratory treponemal } \\
\text { reporting. CDSC }\end{array}$ & $\begin{array}{l}\text { Laboratory surveillance, additional } \\
\text { information completed by clinicians sending } \\
\text { specimen. Currently under review. }\end{array}$ & $\begin{array}{l}6 \text { reference } \\
\text { laboratories }\end{array}$ & $\begin{array}{l}\text { All cases of infectious } \\
\text { syphilis referred to } \\
\text { reference laboratory for } \\
\text { confirmation }\end{array}$ & $1996-$ & $\begin{array}{l}\text { Age, sex, country of } \\
\text { birth, ethnicity, } \\
\text { source of specimen }\end{array}$ & $\begin{array}{l}\text { Sexual orientation, country } \\
\text { where infection acquired and } \\
\text { partners infection, pregnancy }\end{array}$ & $\begin{array}{l}\text { Final syphilis } \\
\text { diagnosis }\end{array}$ & 69 \\
\hline $\begin{array}{l}\text { Enhanced surveillance for } \\
\text { infectious syphilis in the London } \\
\text { Region. CDSC. }\end{array}$ & $\begin{array}{l}\text { An enhanced study to monitor the number of } \\
\text { cases and associated risk factors for } \\
\text { infectious syphilis in London. Established in } \\
\text { response to clusters of syphilis in } \\
\text { homosexual men. }\end{array}$ & London & $\begin{array}{l}\text { All cases of infectious } \\
\text { syphilis (primary, } \\
\text { secondary, and early } \\
\text { latent) diagnosed at GUM } \\
\text { clinics }\end{array}$ & April 2001- & $\begin{array}{l}\text { Sex, age, county of } \\
\text { birth, ethnicity }\end{array}$ & $\begin{array}{l}\text { Sexual orientation, relevant } \\
\text { social networks, reason for } \\
\text { attending, number of sexual } \\
\text { partners, where infection likely } \\
\text { acquired, commercial sex } \\
\text { workers }\end{array}$ & $\begin{array}{l}\text { Stage of infection, } \\
\text { HIV status (if } \\
\text { known) }\end{array}$ & 36 \\
\hline $\begin{array}{l}\text { HIV infection surveillance } \\
\text { HIV laboratory reports. CDSC }\end{array}$ & Reporting system from laboratories & National & $\begin{array}{l}\text { All newly diagnosed HIV } \\
\text { infections }\end{array}$ & $1985-$ & Sex, age, ethnicity & $\begin{array}{l}\text { Likely route of infection and } \\
\text { location of infection if } \\
\text { acquired heterosexually. } \\
\text { Previous negative tests. }\end{array}$ & HIV-1/2 infection & 39 \\
\hline AIDS case reports. CDSC & Reporting system from clinicians & National & $\begin{array}{l}\text { All newly diagnosed AIDS } \\
\text { cases }\end{array}$ & 1985-99 & $\begin{array}{l}\text { Sex, age, ethnicity, } \\
\text { country of birth }\end{array}$ & $\begin{array}{l}\text { Likely route of infection and } \\
\text { location of infection if this is } \\
\text { ongoing heterosexual spread. } \\
\text { Previous negative tests }\end{array}$ & $\begin{array}{l}\text { AIDS case } \\
\text { diagnoses. } \\
\text { Pre-AIDS ARV } \\
\text { treatment }\end{array}$ & 39 \\
\hline Clinician HIV reporting. CDSC & Reporting system from clinicians & National & $\begin{array}{l}\text { All newly diagnosed HIV } \\
\text { infections }\end{array}$ & 2000 & $\begin{array}{l}\text { Sex age, ethnicity, } \\
\text { country of birth, date } \\
\text { of entry to UK }\end{array}$ & $\begin{array}{l}\text { Various, depending on likely } \\
\text { route of infection., including } \\
\text { year of first sex, previous HIV } \\
\text { tests, GUM clinic attendance } \\
\text { and pregnancy history. }\end{array}$ & $\begin{array}{l}\text { AIDS case } \\
\text { diagnoses. } \\
\text { Pre-AIDS ARV } \\
\text { treatment }\end{array}$ & 39 \\
\hline $\begin{array}{l}\text { HIV infection route follow up. } \\
\text { CDSC }\end{array}$ & $\begin{array}{l}\text { Investigation, to interview where necessary } \\
\text { of all newly diagnosed infections with no } \\
\text { identified risk factor for HIV, to establish } \\
\text { likely route of infection, or confirm ongoing } \\
\text { heterosexual transmission in UK. }\end{array}$ & National & $\begin{array}{l}\text { Newly diagnosed HIV } \\
\text { infections reported with no } \\
\text { identified likely route of } \\
\text { infection }\end{array}$ & $1991-$ & $\begin{array}{l}\text { Sex age, ethnicity, } \\
\text { country of birth, date } \\
\text { of entry to UK, } \\
\text { marital status }\end{array}$ & $\begin{array}{l}\text { Detailed sexual behaviour, } \\
\text { including previous STI and HIV } \\
\text { test behaviour }\end{array}$ & HIV diagnosis & 40 \\
\hline $\begin{array}{l}\text { Survey of prevalent HIV } \\
\text { infections diagnosed (SOPHID). } \\
\text { CDSC }\end{array}$ & $\begin{array}{l}\text { Annual cross sectional survey of all HIV } \\
\text { diagnosed individuals receiving care }\end{array}$ & National & $\begin{array}{l}\text { Prevalent diagnosed HIV } \\
\text { infections }\end{array}$ & 1995- & Sex, age, ethnicity & Likely route of infection & $\begin{array}{l}\mathrm{CD} 4 \text { count, level of } \\
\text { antiretroviral } \\
\text { therapy }\end{array}$ & 41 \\
\hline $\begin{array}{l}\text { Unlinked anonymous survey of } \\
\text { dried blood spots. CDSC }\end{array}$ & $\begin{array}{l}\text { Repeated cross sectional survey unlinking } \\
\text { and testing residual infant blood collected } \\
\text { for metabolic testing for maternal HIV } \\
\text { antibody }\end{array}$ & $\begin{array}{l}\text { National } \\
\text { (6 regions) }\end{array}$ & $\begin{array}{l}\text { Pregnant women giving } \\
\text { birth }\end{array}$ & 1992- & $\begin{array}{l}\text { Age, ethnicity, } \\
\text { country of birth, } \\
\text { area of residence }\end{array}$ & & $\begin{array}{l}\text { Infant blood tested } \\
\text { for maternal HIV } \\
\text { antibody }\end{array}$ & 42 \\
\hline
\end{tabular}

Table 1 Data currently available from HIV and STI surveillance-ongoing surveillance 


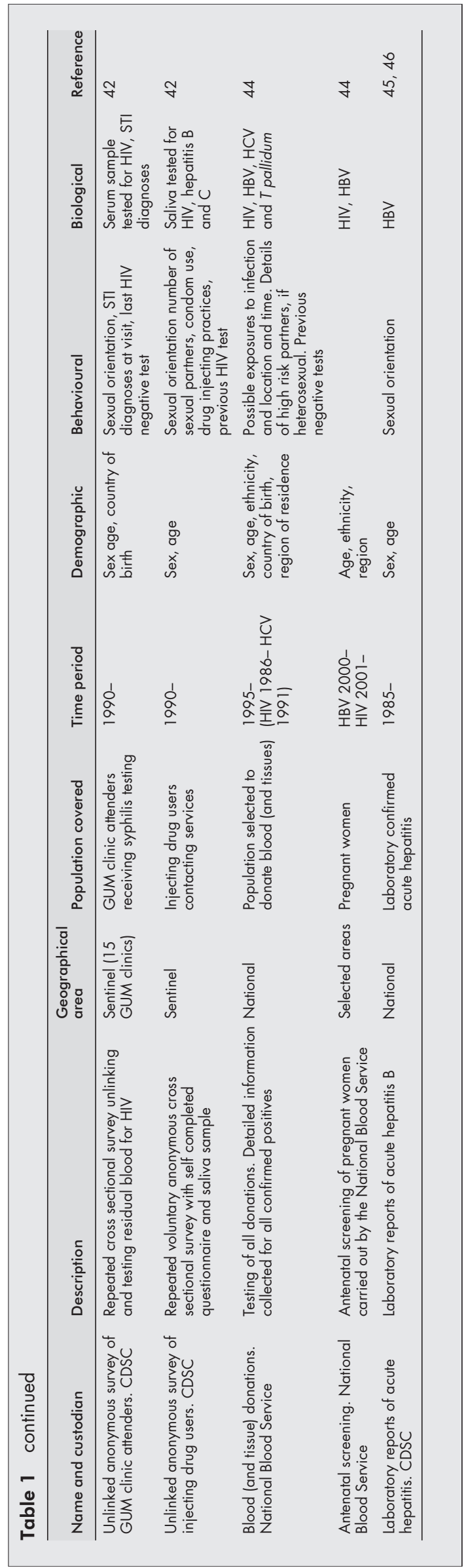

also collected and tested urine samples for genital Chlamydia trachomatis using ligase chain reaction (LCR) techniques to provide the first national prevalence estimates. ${ }^{48}$ The second, the Omnibus survey is a multipurpose survey of the adult population routinely carried out by the Office for National Statistics. A module on contraceptive use and general sexual health including condom use has been included annually since $1997^{49}$ (table 2 ).

A national survey of young people is currently being carried out by the Teenage Pregnancy Unit, as part of an evaluation of the teenage pregnancy strategy (table 2). An individual based tracking survey will be repeated three times a year to collect information from young people aged 13-21 and parents of young people aged $10-17$ over a 3 year period. It will collect information on knowledge, attitudes, and behaviours around sex and relationships. ${ }^{50}$

A number of annual surveys of homosexual men attending social venues, ${ }^{51-53}$ GUM clinics, ${ }^{51}$ and Gay Pride events ${ }^{54}$ are currently carried out ( table 2 ). These use a stable set of behavioural indicators that can be monitored repeatedly. The three surveys developed and used a common set of core behaviour questions that allow comparisons of the three populations of MSM. A number of other surveys of injecting drug users 556 and among ethnic minorities ${ }^{24} 5758$ have also been carried out but none have been sustained. There is clearly a need for more ongoing investment and support to continue projects once established.

\section{HOW DO WE USE BEHAVIOURAL DATA?}

Behavioural surveillance data can be used in a number of ways. They can allow the monitoring of the risk behaviours underlying HIV and STI transmission over time. UNAIDS has recommended that behavioural data collection should be a central part of HIV and STI surveillance programmes. ${ }^{289}$

A range of indicators can be used to measure the effectiveness of both HIV and STI prevention interventions in England and Wales. These include the behavioural determinants of disease transmission (for example, condom use, reported sexual partnerships) as well as disease incidence and prevalence in England and Wales. These "prevention indicators" have been developed to monitor four key areas relevant to HIV transmission and disease prevention and include HIV prevalence, HIV incidence, risk behaviour, and healthcare utilisation. ${ }^{42}$ The indicators for monitoring the success (or failure) of HIV prevention in men who have sex with men are illustrated in table 3. Similar indicators have been used elsewhere, ${ }^{25}{ }^{26}$ although the use of behaviour change as a proxy marker for STI incidence has raised debate. ${ }^{61}{ }^{62}$ The disproportionate effect of some factors on the transmission dynamics of STI means that reported risk behaviour doesn't entirely correlate with transmission. The role of sexual networks in transmission is important and behavioural surveillance cannot always measure these. Prevention indicators have been evaluated in a number of settings, however, and found to be useful for measuring the success of prevention programmes, although multiple sources of data are necessary to provide context. ${ }^{63}$ This in turn facilitates more effective HIV prevention and community planning. Prevention indicators may be developed using a variety of available data within ongoing surveillance systems. This allows the interpretation of HIV and STI trends within different population groups, and through the monitoring of risk behaviours, can indicate when outbreaks of infection may occur. $^{64}$

A potential research priority highlighted in the new national strategy for sexual health and HIV was a need for better understanding of the sexual networks, health seeking behaviour, and risk behaviour of targeted groups. ${ }^{65}$ The monitoring of behavioural indicators within different population groups would provide data on both health seeking behaviours 
Table 2 Behavioural surveillance data currently available from external academic and research groups,-ongoing surveillance

\begin{tabular}{|c|c|c|c|c|c|c|c|c|}
\hline Name and custodian & Description & $\begin{array}{l}\text { Geographical } \\
\text { area }\end{array}$ & Population covered & Time period & Demographic & Behavioural & Biological & Reference \\
\hline $\begin{array}{l}\text { National Survey of Sexual } \\
\text { Attitudes and lifestyles (I and II). } \\
\text { Department of STD Royal Free } \\
\text { and University College Medical } \\
\text { School. }\end{array}$ & $\begin{array}{l}\text { A survey of sexual attitudes and lifestyles in } \\
\text { British population, using stratified probability } \\
\text { sample of men and women aged 16-44. } \\
\text { Interviews using CAPI and CASI }\end{array}$ & National & $\begin{array}{l}\text { General population, } \\
11161 \text { surveyed }\end{array}$ & 2000 & $\begin{array}{l}\text { Ethnic, } \\
\text { socioeconomic, and } \\
\text { demographic data }\end{array}$ & $\begin{array}{l}\text { Sexual behaviour and } \\
\text { attitudes, including partner } \\
\text { formation, sexual mixing and } \\
\text { STI acquisition }\end{array}$ & $\begin{array}{l}\text { Urine sample } \\
\text { tested for } \\
\text { chlamydia }\end{array}$ & 13 \\
\hline $\begin{array}{l}\text { Omnibus Study, Office for } \\
\text { National Statistics. }\end{array}$ & $\begin{array}{l}\text { Multipurpose survey of population. } \\
\text { Interviewing carried out each month; } \\
\text { questions cover a variety of topics reflecting } \\
\text { different users requirements. Random } \\
\text { probability sample of } 3000 \text { private } \\
\text { households selected monthly using postcode } \\
\text { address file as sampling frame. Uses CAPI }\end{array}$ & National & $\begin{array}{l}\text { General population, adults } \\
\text { aged } 16 \text { and over }\end{array}$ & 1997- & $\begin{array}{l}\text { Age, ethnicity, } \\
\text { residence }\end{array}$ & $\begin{array}{l}\text { Contraception, condom use, } \\
\text { sexual orientation, number of } \\
\text { sexual partners in past year, } \\
\text { knowledge of STIs }\end{array}$ & & 49 \\
\hline $\begin{array}{l}\text { Evaluation of teenage } \\
\text { pregnancy strategy. Tracking } \\
\text { survey. Teenage pregnancy } \\
\text { unit. London School of Hygiene } \\
\text { and Tropical Medicine, } \\
\text { University College London and } \\
\text { BMRB Social Research. }\end{array}$ & $\begin{array}{l}\text { Individual based tracking survey of } \\
\text { knowledge attitudes and behaviour, using } \\
\text { random location sampling. Fieldwork } \\
\text { included } 200 \text { sampling panels in England } \\
\text { using areas with higher density of } 13-44 \\
\text { year olds. Interviews using CAPI, and self } \\
\text { completion for sex questions }\end{array}$ & National & $\begin{array}{l}12150 \text { young people } \\
\text { (aged } 13-21 \text { ) and parents } \\
\text { of young people (aged } \\
10-17) .\end{array}$ & $\begin{array}{l}\text { Oct 2000- March } \\
2003\end{array}$ & $\begin{array}{l}\text { Age, sex, } \\
\text { socioeconomic status }\end{array}$ & $\begin{array}{l}\text { Knowledge attitudes and } \\
\text { behaviour around sex and } \\
\text { relationships and impact of } \\
\text { awareness of teenage } \\
\text { pregnancy strategy's media } \\
\text { campaign }\end{array}$ & & 50 \\
\hline $\begin{array}{l}\text { Gay Men's Sexual Health } \\
\text { Survey. Department of Sexually } \\
\text { Transmitted Diseases. Royal } \\
\text { Free and University College } \\
\text { Medical School. }\end{array}$ & $\begin{array}{l}\text { Repeated cross sectional survey to estimate } \\
\text { prevalence of high risk sexual behaviour } \\
\text { among homo/bisexual men in London. Sites } \\
\text { selected to be representative of GUM clinics } \\
\text { and commercial venues. Original sampling } \\
\text { frame defined using a register of all known } \\
\text { primarily gay venues in London }\end{array}$ & $\begin{array}{l}\text { Inner London, } \\
\text { Brighton and } \\
\text { Manchester in } \\
2000\end{array}$ & $\begin{array}{l}\text { Homosexual men resident, } \\
\text { socialising or using sexual } \\
\text { health services in London }\end{array}$ & 1996- & $\begin{array}{l}\text { Age, ethnicity, } \\
\text { residence, education } \\
\text { and employment } \\
\text { and health service } \\
\text { use including } \\
\text { perceived HIV status } \\
\text { and HIV testing } \\
\text { history. }\end{array}$ & $\begin{array}{l}\text { Number of sexual partners, } \\
\text { age of first anal intercourse, } \\
\text { age of last sex partner, } \\
\text { condom use and HIV status of } \\
\text { UAl partners }\end{array}$ & $\begin{array}{l}\text { Saliva sample, } \\
\text { tested for HIV, } \\
\text { since } 2000\end{array}$ & 51 \\
\hline $\begin{array}{l}\text { Gay Men's Sex Survey. Sigma } \\
\text { Research. }\end{array}$ & $\begin{array}{l}\text { Repeated cross sectional survey of } \\
\text { homo/bisexual men. Self completed } \\
\text { questionnaire. Questions vary by city, but set } \\
\text { of core questions collected through the study } \\
\text { period. Additional recruitment has been } \\
\text { done through HIV health promotion agencies } \\
\text { and free gay newspaper }\end{array}$ & $\begin{array}{l}\text { National (7 } \\
\text { cities) }\end{array}$ & $\begin{array}{l}\text { Homo/bisexual men } \\
\text { attending Gay Pride } \\
\text { festivals and events }\end{array}$ & $\begin{array}{l}\text { 1993- (excluding } \\
\text { 1996) }\end{array}$ & $\begin{array}{l}\text { Age, ethnicity, } \\
\text { education, } \\
\text { residence, health } \\
\text { service use including } \\
\text { previous HIV tests, } \\
\text { perceived HIV status } \\
\text { and previous STIs }\end{array}$ & $\begin{array}{l}\text { Sexual behaviour and } \\
\text { attitudes including condom } \\
\text { use, number of partners, } \\
\text { serostatus of partners }\end{array}$ & & 54 \\
\hline $\begin{array}{l}\text { The } 4 \text { Gym Study. Camden and } \\
\text { Islington Community Health } \\
\text { Services NHS Trust and The } \\
\text { Royal Free Hospital School of } \\
\text { Medicine }\end{array}$ & $\begin{array}{l}\text { Repeated cross sectional questionnaire } \\
\text { survey of MSM attending gyms, including } \\
\text { peer education evaluation }\end{array}$ & Inner London & $\begin{array}{l}\text { Homosexual men attending } \\
5 \text { gyms in inner London }\end{array}$ & $1997-$ & $\begin{array}{l}\text { Age, residence, } \\
\text { ethnicity, education }\end{array}$ & $\begin{array}{l}\text { Sexual orientation, drug use, } \\
\text { last HIV test, number of sexual } \\
\text { partners, HIV status of partners }\end{array}$ & & 52 \\
\hline $\begin{array}{l}\text { Royal Free Hampstead NHS } \\
\text { Trust Hospital }\end{array}$ & $\begin{array}{l}\text { Repeated cross sectional questionnaire } \\
\text { survey of all attending for HIV tests within a } \\
\text { period of time. Investigates the sexual } \\
\text { behaviours of those seeking HIV tests } \\
\text { Comparison of behaviours of first testers } \\
\text { with repeat testers. }\end{array}$ & $\begin{array}{l}\text { One London } \\
\text { HIV testing } \\
\text { clinic }\end{array}$ & $\begin{array}{l}\text { Population attending HIV } \\
\text { testing clinic including } \\
\text { heterosexuals and } \\
\text { homosexuals }\end{array}$ & $\begin{array}{l}1995-6,1998-9, \\
2002-3\end{array}$ & $\begin{array}{l}\text { Age, ethnicity, } \\
\text { residence, education }\end{array}$ & $\begin{array}{l}\text { Number of sexual partners, } \\
\text { health care use, previous HIV } \\
\text { tests, reason for tests }\end{array}$ & HIV test result & 70 \\
\hline
\end{tabular}


Table 3 Prevention indicators for HIV and hepatitis transmission in homo/bisexual men

\begin{tabular}{|c|c|c|c|}
\hline & Area & Subcategory & \\
\hline \multicolumn{4}{|l|}{ Prevalence markers } \\
\hline \multirow[t]{2}{*}{ New diagnoses of HIV infections } & UK & $\begin{array}{l}<25 \\
>25\end{array}$ & \\
\hline & & & \\
\hline Prevalent diagnosed HIV infections receiving care & England & All & \\
\hline First HIV tests at six sentinel laboratories & England & $\begin{array}{l}\text { Total } \\
\text { Proportion positive }\end{array}$ & \\
\hline \multirow{2}{*}{$\begin{array}{l}\text { Prevalence of previously undiagnosed HIV infection in GUM } \\
\text { clinic attenders } \dagger\end{array}$} & London & $<25$ & \\
\hline & Elsewhere in England and Wales & $<25$ & \\
\hline \multicolumn{4}{|l|}{ Incidence markers } \\
\hline Median age at diagnosis of HIV infection & UK & All & \\
\hline Median CD4 counts at year of HIV infection diagnosisł & England and Wales & $\begin{array}{l}<25 \\
>25\end{array}$ & \\
\hline $\begin{array}{l}\text { Laboratory reports of acute hepatitis B acquired through sex } \\
\text { between men }\end{array}$ & England and Wales & All & \\
\hline \multicolumn{4}{|l|}{ Markers of risk } \\
\hline Homosexually acquired gonorrhoea & England and Wales & All & \\
\hline Acute STI in HIV positive GUM clinic attenders & England and Wales & Known positive & $\begin{array}{l}\text { Proportion with STI } \\
\text { Number with STI } \\
\text { Total }\end{array}$ \\
\hline \multirow{2}{*}{$\begin{array}{l}\text { Percentage reporting unprotected anal intercourse in the past } \\
\text { year }\end{array}$} & London & Any partners & \\
\hline & & $\begin{array}{l}\text { Partners of unknown or } \\
\text { serodiscordant HIV status }\end{array}$ & \\
\hline \multicolumn{4}{|l|}{ Markers of healthcare utilisation } \\
\hline Attending GUM clinic in the past year & London & $\begin{array}{l}\text { Proportion } \\
\text { Number }\end{array}$ & \\
\hline Having an HIV test in the past year & London & $\begin{array}{l}\text { Proportion } \\
\text { Number }\end{array}$ & \\
\hline HIV tests carried out at GUM clinics§ & England and Wales & Number & \\
\hline
\end{tabular}

and risk behaviours. Behavioural surveillance could also measure progress towards increased HIV testing of GUM clinic attendees through monitoring HIV testing patterns in different population groups.

Finally, behavioural surveillance data will enable us to identify priority areas for further in-depth epidemiological or socioanthropological research. Much of this research should be developed in collaboration with local academic and service partners in the most vulnerable areas or population groups.

\section{WHAT ARE OUR OPTIONS?}

Behavioural surveillance programmes have now been implemented in the United States, ${ }^{26}{ }^{66}$ Switzerland, ${ }^{25}$ Australia, and Hong Kong. ${ }^{67}$ The United States has formed a HIV/STD Behavioural Surveillance Working Group to build and maintain a behavioural surveillance system for HIV and STI. They have achieved this through developing standardised measures of risk behaviours for comparability of data across systems and used these in monitoring a combination of general population, at-risk populations, and infected populations. Modules of questions have been provided at the national level for states to use as appropriate. ${ }^{66}$ In addition, HIV prevention indicators have been developed, which have set out specific indicators suitable for monitoring at state and local level. Collection of data for these is coordinated at local level.

Canada has similarly combined national behaviour telephone surveys with more targeted behavioural surveys in homosexual men and injecting drug users (IDU) although they have not established nationally standardised modules of questions. Australia has used a combination of targeted behavioural surveys in MSM and IDU, from which key indicators are coordinated nationally with HIV surveillance and incidence data. They are currently moving towards national coordination of STI surveillance, ${ }^{68}$ and the development of a coordinated national approach to collection of behavioural risk factor data. The first national survey of sexual health and sexual behaviour and attitudes administered through telephone interview is currently being carried out. Hong Kong has established a behavioural surveillance system, carrying out an annual general population survey of sexual behaviour in men aged 18-60 using a combination of personal interview and a prerecorded telephone interview using a mobile phone. ${ }^{23}$

A combination of approaches could be used in England and Wales. A behavioural surveillance unit (BSU) within the HIV and STI Division has now been established at the Communicable Disease Surveillance Centre (CDSC). In association with key external partners the unit aims to collate data derived from ongoing local and national sexual behavioural surveillance and research programmes within CDSC and outside.

The BSU will streamline current behavioural data collection through existing surveillance systems. Collaborative partnerships with academic and research institutions involved in behavioural research will be established to define and collate key behavioural indicators relevant to HIV and other STI transmission. These indicators will include sexual behaviours such as number of sexual partners, types of sexual intercourse (vaginal, anal, and oral), and potentially preventative behaviours such as condom use and health service use for HIV and other STI screening. This would give an overview of behaviours at the population level in both the general population and in those with disease. A surveillance system, which will allow the prospective monitoring of the important risk indicators, could then be established.

A set of core questions will be established, which will draw on existing validated questions used in a variety of studies. This will enable improved comparability of data from diverse sources, at both national and local level. It will provide a comprehensive picture of sexual health, which can be monitored over time. 


\section{Key points}

- Surveillance data show large recent rises in STIs in the UK but lack details on the sexual behaviours and mixing patterns underlying these trends

- Behavioural surveillance has successfully monitored the effectiveness of prevention programmes internationally

- Key indicators will be produced from the wealth of existing disease and behavioural survey data available

- The impact of interventions and health promotion strategies on behaviour in England and Wales can be measured using these indicators

As a secondary, longer term objective, the BSU will work towards developing new behavioural surveillance systems for monitoring groups where there are currently inadequate data. Specially designed studies will be developed to complete the knowledge gaps - for example, in primary care and in ethnic minorities, where data cannot be obtained through enhancing existing systems. Again this is likely to be best achieved in partnership with external collaborators.

\section{Authors' affiliations}

C A McGarrigle, K A Fenton, O N Gill, G Hughes, D Morgan, B Evans, HIV/STI Division, Public Health Laboratory Service,

Communicable Disease Surveillance Centre, 61 Colindale Ave, London NW9 5EQ, UK

K A Fenton, Department of Sexually Transmitted Diseases, Royal Free and University College Medical School, Mortimer Market Centre, London WCIE 6AU, UK

\section{REFERENCES}

1 World Bank. World development report 1993. Investing in health. World development indicators. New York. Oxford University Press, 1993.

2 Hughes G, Andrews N, Catchpole M, et al. Investigation of the increased incidence of gonorrhoea diagnosed in genitourinary medicine clinics in England, 1994-6. Sex Transm Infect 2000;76:18-24.

3 Hughes G, Brady A, Catchpole MA, et al. Characteristics of those who repeatedly acquire sexually transmitted infections: a retrospcetive cohort study of attendees at three urban sexually transmitted disease clinics in England. Sex Transm Dis 2001;28:379-86.

4 Low N, Sterne JAC, Barlow D. Inequalities in rates of gonorrhoea and chlamydia between black ethnic groups in south east London: cross sectional study. Sex Transm Infect 2001;77:15-20.

5 Lacey C, Merrick D, Bensley D, et al. Analysis of the sociodemography of gonorrhoea in Leeds, 1989-93. BM 1997;314:1715-18.

6 PHLS, DHSS and PS and the Scottish ISD(D) 5 Collaborative Group. Sexually transmitted infections in the UK: new episodes seen at genitourinary medicine clinics, 1996 to 2001. London: Public Health Laboratory Service, 2001. (www.phls.co.uk/topics_az/hiv_andsti/ epidemiology/sti_data.htm)

7 CDSC. HIV and AIDS in the UK. An epidemiological review: 2000 London: Public Health Laboratory Service, 2001.

8 CDSC. Increased transmission of syphilis in Manchester. Commun Dis Rep CDR Wkly 2000;10:89

9 CDSC. Increased transmission of syphilis in men who have sex with men reported from Brighton and Hove. Commun Dis Rep CDR Wkly 2000;10:177-80.

10 CDSC. An outbreak of infectious syphilis in Bristol. Commun Dis Rep CDR Wkly 1997;7:291.

11 CDSC. Outbreak of heterosexually acquired syphilis in Cambridgeshire. Commun Dis Rep CDR Weekly 2000;10:401-4.

12 Higgins SP, Sukthankar A, Mahto M, et al. Syphilis increases in Manchester, UK. Lancet 2000;355: 1466.

13 Johnson AM, Mercer CH, Erens B, et al. Sexual behaviour in Britain: partnerships, practices, and HIV risk behaviours. Lancet 2001;358: 1835-42

14 Berglund T, Fredlund H, Giesecke J. Epidemiology of the reemergence of gonorrhea in Sweden. Sex Transm Dis 2001;28:111-14.

15 Dupin N, Jdid R, N'Guyen YT, et al. Syphilis and gonorrhoea in Paris: the return. AIDS 2001;15:814-15.

16 Chodynicka B, Serwin A, Janczylo-Jankowska M, et al. Epidemiology of syphilis and gonorrhoea in eastern Poland in the years 1988-1997. Int J STD AIDS 1999:10:680-4.

17 Hegyi V, Danilla T. Actual trends of the incidence of syphilis and gonorrhoea in the Slovak Republic in the years 1990-6. Sex Transm Dis 1998;74:376-7

18 CDC. Increases in unsafe sex and rectal gonorrhea among men who have sex with men - San Francisco, California, 1994-1997. MMWR $1999 ; 48: 45-8$
19 CDC. Gonorrhea: United States, 1998. MMWR 2000:49:538-42.

20 CDC. Outbreak of syphilis among men who have sex with men: southern California, 2000. MMWR 2001;50:117-20.

21 Kitsiripornchai S, Markowitz LE, Ungchusak K, et al. Sexual behavior of young men in Thailand: regional differences and evidence of behavior change. J Acquir Immune Defic Syndr Hum Retrovirol 1998; 18:282-8.

22 Gorbach PM, Sopheab H, Phalla T, et al. Sexual bridging by Cambodian men: potential importance for general population spread of STD and HIV epidemics. Sex Transm Dis 2000;27:320-6.

23 Lau JT, Wong WS. Behavioural surveillance of sexually-related behaviours for the cross-corder traveller population in Hong Kong: the evaluation of the overall effectiveness of relevant prevention programmes by comparing the results of two surveillance surveys. Int J STD AIDS 2000;11:719-27.

24 Asiimwe-Okiror G, Opio AA, Musinguzi J, et al. Change in sexual behaviour and decline in HIV infection among young pregnant women in urban Uganda. AIDS 1997;1 1:1757-63.

25 Dubois-Arber $F$, Jeanin A, Spencer B. Long term evaluation of a national AIDS prevention strategy: the case of Switzerland. AIDS 1999; 13:2571-82

26 Rugg DL, Heitgerd JL, Cotton DA, et al. CDC HIV prevention indicators: monitoring and evaluating HIV prevention in the USA. AIDS 2000; 14:2003-13.

27 Catchpole $M$, Harris J, Renton A, et al. Surveillance of sexually transmitted infections: fit for purpose? Int J STD AIDS 1999;10:493-4.

28 UNAIDS/WHO Working Group on Global HIV/AIDS and STI Surveillance. Guidelines for Second Generation HIV Surveillance. World Health Organization and the Joint United Nations Programme on HIV/AIDS, 2000

29 Fenton KA, Johnson AM, McManus S, et al. Measuring sexual behaviour: methodological challenges in survey research. Sex Transm Infect 2001;75::84-92

30 CDC. Prevalence of risk behaviours for HIV infection among adults-United States, 1997. MMWR Morb Mortal Wkly Rep 2001;50:262-5.

31 Saunders P, Mathers J, Parry J, et al. Identifying 'non-medical' datasets to monitor community health and well-being. J Public Health Med 2001;23:103-8.

32 Simms I, Nicoll A. Sexual health in England: a guide to national and local surveillance and monitoring data. London: Health Education Authority, 2000.

33 Ross RW, Tikkanen R, Mansson SA. Internet samples and conventional samples of men who have sex with men: implications for research and HIV interventions. Soc Sci Med 2000;51:749-58.

34 Elford J, Bolding G, Sherr L. Seeking sex on the Internet and sexual risk behaviour among gay men using London gyms. AIDS 2001;15:140915

35 Nardone A, Frankis JS, Dodds JP, et al. A comparison of high-risk sexua behaviour and HIV testing amongst a bar-going sample of homosexual men in London and Edinburgh. Eur J Public Health 2001;11:185-9.

36 CDSC. Preliminary results of enhanced surveillance of infectious syphilis in London. Commun Dis Rep CDR Wkly [serial online] 2002 [cited 31 January 2002]; 12(5): available from www.phls.co.uk/publications/cdr/ PDFfiles/2002/cdr0502.pdf.

37 GRASP Steering Group. The gonococcal resistance to antimicrobials surveillance programme (GRASP) year 2000 report. London: Public Health Laboratory Service, 2001.

38 Hughes G, Catchpole M, Fenton K, et al. Comparison of risk factors for four sexually transmitted infections: results from a study of attenders at three genitourinary medicine clinics in England. Sex Transm Infect 2000;76:262-7.

39 CDSC. HIV and AIDS in the United Kingdom: monthly report - October 2001. Commun Dis Rep CDR Wkly [serial online] 2001 [cited 29 November 2001]; 1 (48): available from: www.phls.co.uk/publications/ cdr/PDFfiles/2001/cdr4801.pdf

40 Gilbart VL, Evans BG, Noone A et al. Second generation heterosexual transmission of HIV-1 infection. CDR 1992;2:R55-9.

41 Molesworth AM. Results of a survey of diagnosed HIV infections prevalent in 1996 in England and Wales. Commun Dis Pub Health $1998 ; 1: 271-5$.

42 Unlinked Anonymous HIV Surveys Steering Group. Prevalence of HIV and hepatitis infections in the United Kingdom 2000. London: Department of Health, 2001

43 Noone A, Durante AN, Brady AR, et al. HIV infection in injecting drug users attending centres in England and Wales, 1990-1991. AIDS 1993; 7:1501-7.

44 CDSC. Surveillance of viral infections in donated blood: England and Wales, 2000. Commun Dis Rep CDR Wkly [serial online] 2001 (cited 25 October 2001); 11 (43): available from: www.phls.co.uk/ publications/cdr/PDFfiles/2001/cdr4301.pdf.

45 Balogun MA, Ramsay ME, Fairley CK, et al. Acute hepatitis B infection in England and Wales: 1985-96. Epidemiol Infect 1999;122:125-31.

46 Ramsay ME, Balogun MA, Collins M, et al. Laboratory surveillance of hepatitis $C$ virus infection in England and Wales: 1992 to 1996. Commun Dis Pub Health 1998;1:89-94.

47 Johnson A, Wadsworth J, Wellings K, et al. Sexual attitudes and lifestyles. Oxford: Blackwell Scientific Publications, 1994

48 Fenton KA, Korovessis C, Johnson AM, et al. Sexual behaviour in Britain: reported sexually transmitted infections and prevalent genital Chlamydia trachomatis infection. Lancet 2001;358:1851-4.

49 Dawe F, Meltzer H. Contraception and sexual health, 2000. London: Office for National Statistics, 2002. 
50 BMRB International. Evaluation of the teenage pregnancy strategy. Tracking survey. Report of results of benchmark wave. LSHTM, UCL, BMRB International, 2001.

51 Dodds J, Nardone A, Mercey D, et al. Increase in high risk sexual behaviour among homosexual men, London 1996-8: cross sectional, questionnaire study. BN 2000;320:1510-11.

52 Elford J, Bolding G, Maguire M, et al. Gay men, risk and relationships. AIDS 2001:15:1053-5.

53 Hart GJ, Flowers P, Der GJ, et al. Homosexual men's HIV related sexual risk behaviour in Scotland. Sex Transm Infect 1999;75:242-6.

54 Hickson F, Reid D, Weatherburn P, et al. Time for more. Findings from the National Gay Men's Sex Survey 2000. London: Sigma Research, 2001.

55 Stimson GV, Hunter GM, Donoghoe MC, et al. HIV-1 prevalence in community-wide samples of injecting drug users in London, 1990-1993. AIDS 1996;10:657-66.

56 Hunter GM, Donoghoe MC, Stimson GV, et al. Changes in the injecting risk behaviour of injecting drug users in London, 1990-1993. AIDS 1995;9:493-501.

57 Evans BA, Bond RA, Macrae KD. Racial origin, sexual behaviour, and genital infection among heterosexual men attending a genitourinary medicine clinic in London (1993-4). Sex Transm Infect 1998;74:40-4.

58 Fenton KA, Chinouya M, Davidson O, et al. HIV transmission risk among sub-Saharan Africans in London travelling to their countries of origin. AIDS 2001;15:1442-5.

59 UNAIDS/WHO Working Group on Global HIV/AIDS and STI Surveillance. Guidelines for sexually transmitted infections surveillance. Geneva: World Health Organization and the Joint United Nations Programme on HIV/AIDS, 1999
60 Mertens T, Caraël M, Sato $P$, et al. Prevention indicators for evaluating the progress of national AIDS programmes. AIDS 1994;8:1359-69

61 Peterman TA, Lin LS, Newman DR, et al. Does measured behavior reflect STD risk? An analysis of data from a randomised controlled behavioral intervention study. Project RESPECT Study Group. Sex Transm Dis 2000;27:446-51.

62 Fishbein $M$, Jarvis B. Falure to find a surrogate for STD incidence-what does it really mean? Sex Transm Dis 2000;27:452-5.

63 Page-Shafer K, Kim A, Norton P, et al. Evaluating national HIV prevention indicators: a case study in San Francisco. AIDS 2000;14:2015-26

64 Aral SK, Berman SM, Aral SO. Anticipating Outbreaks: A prevention role for integrated information systems. Sex Transm Dis 2002;29:6-12.

65 Department of Health. The national strategy for sexual health and HIV. London: DoH, 2001.

66 Reitmeijer CA, Lansky A, Anderson JE, et al. Developing standards in behavioral surveillance for HIV/STD prevention. AIDS Educ Prev $2001 ; 13: 268-78$

67 Lau JTF, Siah PC. Behavioural surveillance of sexually-related risk behaviours of the Chinese male general population in Hong Kong: a benchmark study. AIDS Care 2001;13:221-32.

68 Dore GJ, Kaldor JM. Sexually transmitted diseases surveillance in Australia: towards a coordinated national system. Commun Dis Intell 1998;22:49-52.

69 CDSC. Sexually transmitted diseases quarterly report: syphilis in the United Kingdom. Commun Dis Rep CDR Wkly [serial online] 2001 [cited 29 November 2001]; 11 (48): available from www.phls.co.uk/ publications/cdr/PDFfiles/2001/cdr4801.pdf

70 Leaity S, Sherr L, Wells H, et al. Repeat HIV testing: high-risk behaviour or risk reduction strategy? AIDS 2000;14:547-52.

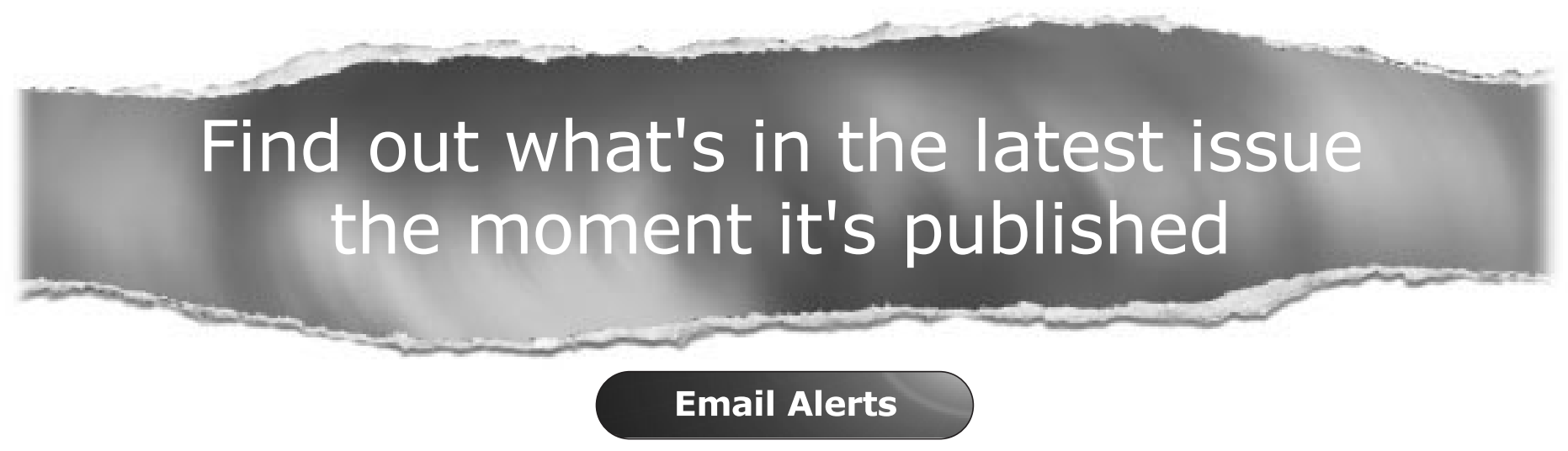

Sign up to receive the table of contents by email every month. You can select from three alerts:

Table of Contents (full), TOC Awareness (notice only); Sexually Transmitted Infections related announcements.

\section{www.sextransinf.com}




\section{LETTERS}

If you have a burning desire to respond to a paper published in Sex Transm Inf, why not make use of our "rapid response" option?

Log on to our website (www.sex transinf.com), find the paper that interests you, click on "full text" and send your response by email by clicking on "eletters submit a response".

Providing it isn't libellous or obscene, it will be posted within seven days. You can retrieve it by clicking on "read eletters" on our homepage.

The editors will decide, as before, whether to also publish it in a future paper issue.

\section{Enhanced risk of HIV sexual transmission during structured treatment interruption}

We report a case of HIV transmission through sexual intercourse while the sexual partner underwent antiretroviral structured treatment interruption. We would like to underline that giving proper information about a higher contamination risk during structured treatment interruption is a critical issue. Moreover, we consider that it is the responsibility of a medical investigator and physician to deliver a clear message in order to reinforce prophylaxis indications for sexual intercourse during this period.

A patient was infected with HIV for 9 years when he started HAART. At this time, his CD4 count was $280 \times 10^{6} / 1$ and plasma viral load was $5.1 \log _{10} / \mathrm{ml}$. A first structured treatment interruption (2 months' duration) was proposed after 2 years, while plasma viral load was undetectable. He was asked to use preservatives strictly at this time. A peak of HIV replication was observed $\left(4.3 \log _{10} / \mathrm{ml}\right)$. Treatment was then reintroduced. One year later, he was still healthy (CD4 count $450 \times$ $10^{6} / 1$ and undetectable plasma viral load). $\mathrm{He}$ asked for a new structured treatment interruption. Plasma viral load reached $4.6 \log _{10} / \mathrm{ml}$ 2 months later.

This homosexual man had a regular HIV negative sexual partner for 2 years. His HIV serology was found to be negative 2 months before the second structured treatment interruption. This sexual partner experienced a short period of unexplained fever 2 months after his boyfriend's treatment was discontinued. He was found to be HIV positive 4 months after structured treatment interruption. He denied having had any sexual relationship with other sexual partners during this period, as well as any other risk factor for HIV transmission. Moreover, genetic sequencing of the viruses, which was performed in both patients at the same date, revealed minor mutations on the protease gene (L63P, A7IV, and V77I) in both patients without any mutation on reverse transcriptase, which is another point to suggest the virus transmission by our patient

Our HIV infected patient told us that he practised safe sex systematically during the first years of HIV infection, but that it was less systematic when viral load became undetectable (around 20\% of unprotected sexual intercourse during the past 2 years with this partner). He practised safe sex during the first structured treatment interruption, but not during the second one. Both of them denied any record of sexually transmitted infection except HIV. They were found to be negative for hepatitis B and C and syphilis.

Structured treatment interruption is an attractive strategy currently in evaluation in HIV-l infected patients after long term viral suppression. As far as we know, antiretroviral interruption does not reduce therapy efficacy once reinitiated, delaying the reduction of viral load. ${ }^{1}$ During the phase of drug interruption, plasma HIV RNA rebounds to detectable levels within days of stopping HAART (median increase $0.2 \mathrm{log} /$ day). ${ }^{2}$ HAART treatment decreases HIV RNA concentration in blood and is generally associated with a decrease of seminal HIV RNA. ${ }^{3}$ Moreover, an increase of HIV RNA in plasma is known to enhance the risk of transmission. ${ }^{4}$ Finally, we may assume that a sudden increase in HIV RNA in blood during structured treatment interruption may induce a viral rebound in semen.

Some key messages have to be taken into account. Firstly, the impact of sexual transmission during clinical trials assessing the benefit/risk ratio of structured treatment interruption has to be evaluated prospectively as a side effect of the strategy. Secondly, patients have to be informed that they are particularly at risk of HIV transmission during this period and that sexual relations have to be heavily protected when antiretroviral regimen is stopped. It is the responsibility of investigators involved in such trials to inform patients. Thirdly, in order to avoid complaints against physicians, we believe that patients must be informed of this very high risk period.

E Teicher, T Casagrande, D Vittecoq Unité des Maladies Infectieuses, Hôpital Paul Brousse, 94804 Villejuif, France

Correspondence to: Elina Teicher; elina.teicher@pbr.ap-hop-paris.fr

\section{References}

1 Neumann A, Tubiana R, Calvez V, et al and the Comet Study Group. HIV-1 rebound during interruption of highly active antiretroviral therapy has no deleterious effect on reinitiated treatment. AIDS 1999;13:677-83

2 Harrigan R, Whaley M, Montaner J. Rate of HIV RNA rebound upon stopping antiretroviral therapy. AIDS 1999;13:F59-62.

3 Vernazza PL, Gilliam B, Flepp $M$, et al. Effect of antiviral treatment on the shedding of HIV-1 in semen. AIDS 1997;11:1249-54.

4 Pedraza MA, Del Romero J, Roldan F, et al. Heterosexual transmission of HIV-1 is associated with high plasma viral load levels and a positive viral isolation in the infected partner. J Aquir Immune Defic Syndr 1999;21:120-5.

Accepted for publication 30 September 2002

\section{Chaperoning in genitourinary medicine clinics}

In 1996 the General Medical Council recommended, where possible, offering chaperones to patients during intimate examinations. This advice was incorporated into a report from a Royal College of Obstetricians and Gynaecologists working party. ${ }^{1}$ Subsequently, Torrance et al performed a postal survey of practice in 175 genitourinary medicine (GUM) clinics in the United Kingdom. ${ }^{2}$ This study also concluded that chaperones should be offered to patients more widely during genital examinations in genitourinary medicine (GUM) clinics. ${ }^{2}$ In contrast, other studies have shown that male patients are comfortable with genital examinations being performed by doctors of either sex, ${ }^{3}$ and that it is not necessary to provide a chaperone when male patients are examined by a male doctor. ${ }^{4}$

We carried out a postal survey of the use of chaperones in 31 GUM clinics in the North Thames Region in order to assess current practice. Responses were received from 20 centres $(64.5 \%)$. Only two ( $10 \%)$ clinics had a written clinic policy and only one (5\%) had carried out a patient survey on views about the provision of chaperones. None of the clinics had carried out a staff (nurses and doctors) survey of their views about chaperoning.

We identified two interesting observations (table 1). Firstly, there was a significant difference in provision of chaperones for female patients, depending on whether the person carrying out the examination was a female doctor $(12 / 20)$ or a female nurse $(1 / 20)$; Yates's corrected $\chi^{2}$ test $=11.40,1 \mathrm{df}$, $\mathrm{p}<0.001$. Secondly, there was a difference in provision of chaperones for female patients examined by female doctors (12/20) compared with male patients examined by male doctors (2/20); Yates's corrected $\chi^{2}$ test $=8.90$, $1 \mathrm{df}, \mathrm{p}<0.003$ (table $\mathrm{l}$ ).

In addition, it was noted that in 18 clinics not offering routine availability of chaperones for male patients being examined by a male

Table 1 Results of a postal survey of practice in 20 GUM clinics in the North Thames Region

\begin{tabular}{lrr}
\hline & \multicolumn{2}{l}{$\begin{array}{l}\text { Chaperone } \\
\text { offered }\end{array}$} \\
\cline { 2 - 3 } & Yes & No \\
\hline Female patient: & 12 & 8 \\
Female doctor & 1 & 19 \\
Female nurse & 20 & 0 \\
Male doctor & 12 & 0 \\
Male nurse ${ }^{*}$ & & \\
Male patient: & 4 & 15 \\
Female doctor $\ddagger$ & 3 & 15 \\
Female nurse§ & 2 & 18 \\
Male doctor & 1 & 18 \\
Male nurse $\dagger$ & 18 \\
\hline
\end{tabular}

* Seven clinics do not allow this interaction; †one clinic does not have male nurses; łone clinic does not allow the interaction; §two clinics do not allow this interaction. 
doctor or nurse, a chaperone would be offered in six clinics (33\%) for cases of sexual assault, or for colposcopy. A chaperone would also be offered for the procedure of prostatic massage in five clinics (28\%). Several clinics reported that they were more likely to offer chaperones to those patients with a past history of aggressive behaviour towards staff or to those with psychiatric problems.

Our study does not inform the discussion as to who should act as chaperone in GUM clinics. Previous studies in general practice have suggested that adolescent females prefer a female relative to be present during a genital examination. In the context of the GUM clinic, perhaps the specialist nurse or healthcare assistant is the ideal person-as in addition to reassuring the patient, they may aid the examiner and safeguard both patient and healthcare worker against allegations of inappropriate behaviour. In some small clinics this may be an impossible target to meet. However, the time and cost of resolving allegations against healthcare workers must be balanced against the costs of employing appropriate staff.

R Miller, K Jones

Department of Sexually Transmitted Diseases, Royal Free and University College Medical School, University College London, Mortimer Market Centre, London WCIE 6AU, UK

D Daniels

West Middlesex Hospital Sexual Health Clinic, West Middlesex University Hospital, Isleworth

TW7 6AF, UK

G Forster

Ambrose King Centre, The Royal London Hospital, London El IBB, UK

M G Brook

Patrick Clements Clinic, Central Middlesex Hospital, London NW10 7NS, UK

Correspondence to: Rob Miller rmiller@gum.ucl.ac.uk

\section{References:}

1 Royal College of Obstetricians and Gynaecologists. Intimate examinations: report of a working party. London: RCOG, 1997.

2 Torrance CJ, Das R, Allison MC. Use of

chaperones in clinics for genitourinary medicine: survey of consultants. BM 1999;319:159-60

3 Fisk P, Barmi K, Morgan C. Chaperoning male patients. Sex Transm Infect 2000;76:495.

4 O'Mahoney C. Chaperoning male patients. Sex Trans Infect 2000;77:225-6

5 Penn MA, Bourguet CC. Patients' attitudes regarding chaperones during physical examination. J Fam Pract 1992;35:639-43

Accepted for publication 30 September 2002

\section{Cytokine profiles in HIV seropositive patients with tuberculous meningitis}

The immunological response in pulmonary and pleural tuberculosis has been extensively studied. However, the response in tuberculous meningitis has not been well documented. ${ }^{1}$ In pulmonary disease, exposure to tuberculous antigens results in a $\mathrm{T}$ cell and natural killer cellular response, elaborating various cytokines, mainly of T helper type 1 (Thl) origin. Stimulated macrophages elaborate tumour necrosis factor (TNF) $\alpha$, interleukin (IL) 12, and IL 1, promoting further recruitment and activation of macrophages and lymphocytes.

TNF $\alpha$ correlates with disease severity and may contribute to tissue necrosis; however, TNF $\alpha$ has also contributed to survival in mouse studies. ${ }^{2}$ Transforming growth factor $\beta$ (Th3 cytokine) suppresses macrophage activation. IL 2 may be beneficial in promoting an immune response in HIV seropositive patients. Thl and Th2 cytokine responses have been observed in cerebrospinal fluid (CSF) of HIV seronegative patients with tuberculous meningitis. ${ }^{3}$. Whether the response is similar in HIV seropositive patients with tuberculous meningitis is unknown.

We studied the cytokine response and its correlation with disease severity in HIV seropositive and HIV seronegative patients with tuberculous meningitis.

Tuberculous meningitis was diagnosed on clinical and CSF examination after exclusion of viral, acute bacterial, and other causes of aseptic meningitis. Disease severity was assessed according to the Medical Research Council stages 1 to 3. HIV ELISA was done on all patients. CSF samples were subjected to microscopy, culture, protein and glucose analysis, Venereal Disease Research Laboratory test, fluorescent treponemal antibody analysis, cryptococcal antigen analysis, viral studies, cysticercus ELISA, CD4 counts, and determination of concentrations of adenosine deaminase (ADA), CSF IgG, and albumin.

For cytokine assays, CSF was centrifuged at $3000 \mathrm{~g}$, and supernatant was aliquoted and stored at $-70^{\circ} \mathrm{C}$. TNF $\alpha$, interferon (IFN) $\gamma$, and IL 10 concentrations were measured by ELISA kits (Genzyme Diagnostics, Cambridge, Massachusetts, USA) with detection limits of $3 \mathrm{pg} / \mathrm{ml}, 3 \mathrm{pg} / \mathrm{ml}$, and $5 \mathrm{pg} / \mathrm{ml}$, respectively.

Data were summarised as medians and ranges. Non-parametric Wilcoxon rank sum tests were used to compare HIV seropositive groups with HIV seronegative groups, tuberculous meningitis severity groups, and groups derived according to the blood brain barrier index for cytokine concentrations. Spearman's rank correlation was used to derive correlations of cytokine concentration, ADA concentrations, and CD4 counts in CSF.

There were 27 patients: $18(67 \%)$ women and $9(33 \%)$ men. Seventeen were HIV seropositive and 10 HIV seronegative. The average interval between onset of symptoms and the first clinical assessment was 17 days (range 5-90 days) in 18 patients where this was recorded. The mean (SD) age was 26.8 (11.6) years. There was one patient aged 10 and one aged 60, and the rest were between 25 and 40 . The cytokine concentrations were not analysed according to age, as this would make the categories too small and of little value. The
IgG index was calculated for 23 patients. There was no significant difference between the HIV seropositive and HIV seronegative groups for ADA $(\mathrm{p}=0.4)$ and CD4 counts $(\mathrm{p}=0.19)$ in CSF and cytokine concentrations (table 1 ).

Ten patients $(37 \%)$ were classified as having grade 1 tuberculous meningitis. Sixteen $(59 \%)$ had grade 2 and one (4\%) grade 3 , which for analysis was considered to be grade 2 . Table 1 summarises the cytokine concentrations for patients in stages 1 and 2 .

Patients with stage 2 disease had significantly stronger Thl responses. There was no difference in the IL 10 concentrations. The two patients with stage 2 disease who died had very high IFN $\gamma$ concentrations, both greater than $2048 \mathrm{pg} / \mathrm{ml}$.

IL 10 concentrations were moderately positively correlated with IFN $\gamma$ concentrations $(r=0.53)$. The correlation coefficients were -0.18 for IFN $\gamma,-0.33$ for TNF $\alpha$, and -0.34 for IL 10. Correlation coefficients between ADA and cytokine concentrations were 0.34 for IFN $\gamma, 0.47$ for TNF $\alpha$, and 0.22 for IL 10. Cytokine concentrations correlated poorly with CD4 counts in CSF.

It is postulated that in HIV infection a predominant Th2 response accounts for extrapulmonary disease. ${ }^{5}$ This study does not favour a predominance of either Th1 or Th2 in the CSF. It is possible that a Th0 response, which is a non-differentiated response seen early on in immune activation, was seen in our patients, as they were examined untreated and relatively early in the disease. Other investigators have also documented this phenomenon. ${ }^{3}$ The positive correlation between IFN $\gamma$ and IL 10 suggests that these were produced concurrently. This may reflect a control mechanism regulating Thl and Th2 responses.

There was no difference in cytokine and ADA concentrations and CD4 counts between HIV seropositive and HIV seronegative patients. It is known that the clinical response to antituberculous treatment in both groups is similar. ${ }^{5}$ Perhaps this similarity correlates with similar immune responses in both groups. The size of each group is small and a type 1 statistical error has to be considered. Further studies to confirm our findings would be of value.

The significantly greater TNF $\alpha$ and IFN $\gamma$ concentrations in the severe group of tuberculous meningitis is confirmed by other studies ${ }^{6}$ and suggests that disease severity results mainly from the immune response rather than the organism itself.

The lack of correlation between CD4 and cytokine concentrations may be explained by the fact that there are other sources of cytokines in the CSF, namely macrophages and natural killer cells. Concentrations of ADA, which are derived from lymphocytes, are consistent with other reports, where they were correlated with cytokine concentrations.

There was no correlation between the IgG index and cytokine concentrations, suggesting that the blood brain barrier did not

Table 1 Differences between HIV seropositive and HIV seronegative groups and tuberculous meningitis severity

\begin{tabular}{|c|c|c|c|c|c|c|c|c|c|c|}
\hline \multirow[b]{2}{*}{ Cytokine } & \multicolumn{2}{|c|}{ HIV positive } & \multicolumn{2}{|c|}{ HIV negative } & \multirow[b]{2}{*}{$p$ Value } & \multicolumn{2}{|l|}{ Stage 1} & \multicolumn{2}{|l|}{ Stage 2} & \multirow[b]{2}{*}{$\mathrm{p}$ Value } \\
\hline & Median & Range & Median & Range & & Median & Range & Median & Range & \\
\hline IFN $\gamma(p g / m l)$ & 569.9 & $16.0-2048$ & 890.6 & 0-2048 & 0.9 & 184.5 & $0-1771.0$ & 1000.0 & $16.0-2048$ & 0.03 \\
\hline $\mathrm{TNF} \alpha(\mathrm{pg} / \mathrm{ml})$ & 1.6 & $0-67.5$ & 9.8 & $0-309.3$ & 0.11 & 0.65 & $0-19.2$ & 9.8 & $0-309.3$ & 0.008 \\
\hline IL $10(\mathrm{pg} / \mathrm{ml})$ & 24.6 & $0-127.9$ & 17.3 & $0-296.3$ & 0.9 & 3.68 & $0-53.0$ & 27.4 & $0-296.4$ & 0.97 \\
\hline
\end{tabular}

IFN, interferon; II, interleukin; TNF, tumour necrosis factor. 
significantly influence concentrations. Unfortunately, corresponding serum concentrations were not available. This would have been valuable. This is the first study correlating CSF cytokine responses to severity of tuberculous meningitis and comparing HIV positive with HIV negative groups. Further studies should be done to confirm these findings, perhaps to define their relevance to complications and to explore the possibility of IL 2 treatment in HIV positive patients.

Reproduced in full with permission from

J Neurol Neurosurg Psychiatry 2002;73:598-599

\section{Acknowledgements}

This study was sponsored by the Glaxo TB initiative.

VB Patel, Al Bhigjee, PLA Bill

Division of Neurology, Nelson R Mandela School of Medicine, University of Natal, Durban, South

CA Connolly

Biostatistics, Medical Research Council, Durban South Africa

Correspondence to: Dr VB Patel, Department of Neurology, Ward A3, Wentworth Hospital, Private Bag Jacobs, Durban 4026, South Africa; patelv@nu.ac.za

\section{References}

1 Barnes PF, Modlen RL, Milner J. T-cell responses and cytokines in tuberculosis, pathogenesis, protection and control. Washington: BR Bloom American Press, 1994:417-35.

2 Flynn JL, Goldstein MM, Chan J, et al. Tumor necrosis factor-alpha is required in the protective immune response against Mycobacterium tuberculosis in mice. Immunity 1995;2:561-72.

3 Donald PR, Schoeman JF, Beyers N, et al. Concentration of IFN- $\gamma$, TNF- $\alpha$ and IL $1-\beta$ in CSF of children treated for TBM. Clin Infect Dis 1995;21:924-9.

4 Havlir DV, Barnes PF. Tuberculosis in patients with human immunodeficiency virus infection. N Engl J Med 1999:340:367-73.

5 Berger JR. Tuberculous meningitis. Curr Opin Neurol Neurosurg 1994;7:191-200.

6 Thwaites G, Chau TTH, Mai NTH, et al.

Tuberculous meningitis. J Neurol Neurosurg

Psychiatry 2000;68:289-99.

\section{Hepatitis C testing in HIV infected patients}

Numerous seroprevalence studies have shown a high rate of co-infection with hepatitis $C$ among HIV-l infected patients, ranging from $98 \%$ in haemophiliacs, $80 \%$ among injecting drug users, to $3-15 \%$ in homosexual/bisexual men. ${ }^{1}$ Although it is estimated that there are 200 000-400 000 people infected with hepatitis C (HCV) in the United Kingdom, ${ }^{2}$ the number of coinfected individuals is unknown. Data have shown that HIV increases the rate of HCV progression, ${ }^{1}$ and there is also some evidence suggesting that HCV worsens HIV progression, although this is more controversial.

There is a growing recognition of the significant impact of co-infection on the management of HIV disease. Hepatitis morbidity and mortality among coinfected patients has increased fivefold in recent years. Furthermore the presence of HCV increases the frequency of hepatotoxicity with antiretroviral therapy, and may also impact on the choice of antiretroviral drug, with avoidance of drugs that are potentially hepatotoxic such as ritonavir and nevirapine. ${ }^{4}$ Most importantly there is now effective treatment avail able for the management of HCV infection. ${ }^{2}$
Recent preliminary data suggest in HIV-HCV co-infected patients superior virological response in those receiving PEG-interferon with ribavirin compared to standard interferon with ribavirin. ${ }^{5}$ Finally, management of the HIV-HCV co-infected patients involves other interventions such as vaccination for other viral hepatitis $\mathrm{A}$ and $\mathrm{B}$, and reducing alcohol intake.

These findings all highlight the importance of identifying those HIV infected patients who are co-infected with HCV. However, a recent survey at Kings' College Hospital in March 2002 revealed that only $63 \%$ of a cohort of 850 current HIV infected attendees had been tested for HCV. The majority of those not yet tested for HCV were patients who had presented before the routine introduction of HCV testing in 1999. Similar findings have been reported from other European centres. In a French cohort of 4017 HIV infected patients only 2589 (64\%) were tested for $\mathrm{HCV}^{6}$ Although a substantial number of these patients have stored samples available on which retrospective HCV testing could be performed, the current guidance from Royal College of Physicians working group is that consent must be obtained before testing.

Current guidelines from the United States now recommends HCV testing for all HIV infected patients. ${ }^{8}$ Antibody based screening assays for HCV infection have evolved over the past decade and currently the most widely are third generation ELISA assays (Ortho). ${ }^{2}$ Confirmation of positive results by recombinan immunoblot assays (Chiron RIBA, others) is still recommended as a proportion of positive tests may represent false positive results. Qualitative and quantitative PCR (polymerase chain reaction) tests that detect the presence of HCV RNA and have sensitivity in the range of 50-1000 equivalents per $\mathrm{ml}$ are now also available. ${ }^{2}$ We undertook a recent informal survey of 10 UK teaching hospitals, which showed differences in HCV testing policies. Seven clinical sites use serological testing for screening and confirm all initially positive results with a second serological assay, and then confirm positive results with a qualitative PCR test. Three sites use qualitative PCR testing for those with an initial positive serological test. For those with a negative PCR further confirmatory antibody assay are done at two sites and one site requests repeat PCR testing at 6 and 12 months.

What is the role of PCR testing in COinfection? At least $4-7 \%$ of HIV-HCV coinfected patients have no detectable antibodies in the presence of HCV viraemia ${ }^{9}$ as they fail to produce antibodies or have low titres (can't be detected or give equivocal or indeterminate) or loss of detectable antibodies from serum despite persistent viraemia in immunosuppressed patients..$^{10}$ Therefore, additional testing with PCR is often indicated. The guidelines recommend ${ }^{2}$ that all patients with positive HCV antibody tests and those patients thought to be at risk of HCV infection despite negative or indeterminate serological tests should undergo qualitative PCR testing of serum. A positive result confirms curren viraemia whereas a negative test suggests non-viraemic infection. Patients with a a positive ELISA but negative PCR should be tested with recombinant immunoblot assay to confirm antibody status.

In conclusion, we recommend that centres caring for HIV infected patients should develop clear policies and strategies for ensuring all their new and existing HIV infected patients have undergone testing for HCV.
A H Mohsen, P Easterbrook Department of HIV/GU Medicine, The Guys', Kings, and St Thomas's School of Medicine Denmark HII, London SE5 9RJ, UK

Correspondence to: Dr Mohsen; abdul.mohsen@kcl.ac.uk

\section{References}

1 Mohsen A H, Easterbrook P, Taylor C, et al. Hepatitis $C$ and HIV-1 Infection. Gut 2002;51:601-8

2 Bootha J C L, O'Grady J, Neuberger J. Clinical guidelines on the management of hepatitis C, on behalf of the Royal College of Physicians of London and the British Society of Gastroenterology. Gut 2002;49/Suppl I): $11-21$

3 Greub G, Ledergerber B, Battegay $M$, et al, Clinical progression, survival, and immune recovery during antiretroviral therapy in patients with HIV-1 and hepatitis $C$ virus coinfection: the Swiss HIV Cohort Study. Lancet 2000;356: 1800-5.

4 Soriano V, Sulkowski M, Bergin C, et al. Care of patients with chronic hepatitis $C$ and HIV co-infection: recommendations from the HIV-HCV International Panel. AIDS

2002;16:813-28. (Review.)

5 Chung R, Andersen J, Alston B, et al. A randomized, controlled trial of pegylated interferon alpha-2a with ribavirin vs Interferon alpha-2a with ribavirin for the treatment of chronic HCV in HIV co-infection. 9th CROI 2002 (abstract LB-15), http:// www. retroconference.org/2002/Abstract/ $14102 . \mathrm{htm}$

6 Benhamou Y, Di Martino V, Bochet $M$, et al. Factors affecting liver fibrosis in human immunodeficiency virus-and hepatitis $C$ virus-coinfected patients: impact of protease inhibitor therapy. Hepatology 2001;34:283-7.

7 Medical Research Council. Human tissue and biological samples for use in research. www.mrc.ac.uk, April 2001

82001 USPHS/IDSA Guidelines for the Prevention of Opportunistic Infections in Persons Infected with Human Immunodeficiency Virus. www.ama-assn.org/ special/hiv.

9 Bonacini $\mathbf{M}$, Lin HJ, Hollinger FB. Effect of coexisting HIV-1 infection on the diagnosis and evaluation of hepatitis $C$ virus. J AIDS. 2001;26:340-4.

10 Chamot E, Hirchel B, Wintsch J, et al. Loss of antibodies against hepatitis $C$ virus in HIV-seropositive intravenous drug users. AIDS 1990;4:1275-7.

Accepted for publication 10 October 2002

\section{First, do not harm: also an issue in NAA assay diagnostics for chlamydial infection}

In his update on Chlamydia trachomatis diagnostics, ${ }^{1}$ Chernesky emphasises that nucleic acid amplification (NAA) assays can be useful for screening purposes, because of their increased sensitivity and the possibility of non-invasive sample collection. Since the introduction of these assays, many screening interventions have been undertaken and evaluated mostly in an optimal research context. However, a number of problems can be expected if these diagnostics are implemented in large scale routine clinical practice or in community screening programmes.

Firstly, multiple testing sites may be needed for accurate results, ${ }^{1}$ but cannot be realised for reasons of cost and inconvenience.

Secondly, the positive predictive value of a test is low in low prevalence populations. To avoid false positive diagnoses in these situations repeat testing of the sample, preferably by a different technique, is highly recommended. However, in clinical practice a single 
positive result is often considered to indicate that a patient is infected. ${ }^{2}$

Thirdly, reproducibility problems do occur and are varying in time, ${ }^{3}$ and confirmatory testing is required when test results are intermediate or near the cut-off value. A low positive test result that is not caused by the presence of amplification inhibitors points to a low number of target organisms in the sample. Repeat testing is then a matter of statistical chance of the second portion of the sample containing detectable numbers of target organisms. Such results should be transmitted to the clinician accompanied by interpretative comments.

Fourthly, diagnostic accuracy may be affected by contamination of the specimen during laboratory processing

Fifthly, it is not clear whether detection of a very small amount of chlamydial DNA always reflects clinically significant infection: NAA assays might identify residual DNA from a cleared or treated infection, DNA of nonviable organisms, or DNA of levels of pathogens which are too low to be infectious. ${ }^{45}$

For this reasons it is likely that in routine practice a number of results will be interpreted as positive in patients who are not truly infected.

However, the impact of a chlamydia diagnosis on people's lives is considerable, ${ }^{6}$ and can include stigmatisation, anxiety about reproductive health, and potential partner discord. Pre-test and post-test counselling has been shown to be labour intensive for healthcare providers too, since most infections in asymptomatic patients will be unexpected.

To overcome these problems, rigid diagnostic protocols must be developed before introducing any screening programme. Not only should infected people be identified but false positive diagnoses should be avoided. Laboratories should participate in quality control programmes, and test runs should include multiple controls. Healthcare providers should be offered agreed standards to which they can manage the different aspects of screening and counselling for chlamydial infection.

V Verhoeven, M leven, A Meheus, D Avonts, $\mathrm{H}$ Goossens University of Antwerp, Universiteitsplein 1, Wilrijk 2610, Belgium

Correspondence to: Veronique Verhoeven verover@uia.ua.ac.b

\section{References}

1 Chernesky MA. Chlamydia trachomatis diagnostics. Sex Transm Infect 2002;78:232-4.

2 Garrow SC, Smith DW, Harnett GB. The diagnosis of chlamydia, gonorrhea, and trichomonas infections by self obtained low vaginal swabs, in remote northern Australian clinical practice. Sex Transm Infect 2002;78:278-81.

3 Mallinson H, Hopwood J, Mutton K. Resolution of the recent performance problem of Abbott LCx Chlamydia trachomatis assay. Issues of repeat testing for confirmation of chlamydial infection. Sex Transm Infect 2002;78: 225-6.

4 Louie $M$, Louie L, Simor AE. The role of DNA amplification technology in the diagnosis of infectious diseases. CMA 2000; 163:301-9.

5 Turner CF, Rogers SM, Miller HG, et al. Untreated gonococcal and chlamydia infection in a probability sample of adults. JAMA 2002;287:726-33.

6 Duncan B, Hart G, Scoular A, et al. Qualitative analysis of psychosocial impact of diagnosis of Chlamydia trachomatis: implications for screening. BM 2001;322:195-9.

Accepted for publication 17 October 2002

\section{Geographical focusing: an intervention to address increased risk for sexually transmitted diseases during repatriation and resettlement in post-war Mozambique}

Countries in the early post-war phase face population movements contributing to increased vulnerability for sexually transmitted diseases (STD) and HIV. Mozambique chose geographically focused interventions to control STD spread in the first post-war years.

Mozambique was one of the poorest countries in the world in 1993 with per capita GNP of US\$63 and life expectancy of 48 years.

Seventeen years of civil war and economic crisis destabilised the country causing massive population movements towards urban areas and neighbouring countries. Between 1992 and 1995, an estimated 1.7 million refugees from Malawi, Zimbabwe, Tanzania, Zambia, and Swaziland returned, soldiers were demobilised, and internally displaced people resettled. ${ }^{2}$ The war destroyed the health infrastructure, especially in rural areas, precluding provision of STD services and effective primary health care (PHC). ${ }^{3}$

Vulnerable groups and populations of the areas through which the refugees were returning, were considered particularly vulnerable to the risk of STD/HIV.

The National STD/AIDS Control Programme, supported by the European Commission, decided to focus STD/HIV interventions at the PHC level in the areas most affected by population movements

Four studies carried out between 1987-92 showed HIV seroprevalence rates of $3.2 \%$ $4.6 \%$ in displaced populations, higher than the $1.2 \%$ of the general population.

Very high STD prevalence rates $(51 \%)$ were demonstrated in pregnant women attending PHC services for antenatal care. Displaced populations showed lower awareness of condoms than the general population. ${ }^{6}$

Fifteen districts in five provinces were selected on the basis of existing population health facilities and projected influx of people. $^{2}$ PHC services were strengthened overcoming the existing shortages of staff, drugs, and materials. Clinical, laboratory, and health education skills of over 100 PHC workers in these priority districts were upgraded through training. Drugs for STD treatment, condoms, and educational materials were delivered. An existing popular health education initiative using theatre groups expanded, reaching over 100000 people in local languages.

Difficulties encountered were mostly related to the destabilisation due to the war, such as transport problems, demotivation and relocations of health staff, parallel drug and treatment markets, and poor condom availability. Nevertheless, significant progress was noted. One major achievement was the increase in STD patient attendance, quadrupling in one province and doubling or tripling in others. The number of contacts reached also increased significantly: in $1992,4.5 \%$ of STD patients were contacts, in 1993 9\%, and in 1994 20.8\%. Another achievement was increased condom distribution, from 2.5 million in 1993 to 5 million in 1994.
Geographical focusing of interventions in early post-war Mozambique showed significant impact on STD attendance, proving the feasibility of introducing STD care in difficult circumstances. Strengthening 15 districts provided the basis for improvement of the STD programme in other areas and enhanced general functioning of PHC centres in the initial priority districts. Improved supervision, in turn improving clinical, laboratory, and educational activities, was subsequently expanded to other districts. The use of syndromic management protocols contributed positively to STD management throughout the country.

Focusing interventions in areas with especially vulnerable populations, combined with an integrated approach to STD/HIV control, may have contributed to the control of the spread of STD and HIV in early post-war Mozambique.

\section{Acknowledgements}

Grant: European Commission, DG VIII/8, contract No RPR-MOZ-003

The authors would like to thank all those who contributed to this letter and especially Kathy Attawell for her assistance in editing this report and Professor Marleen Temmerman of Ghent University for her encouragement and assistance.

B De Hulsters

Former technical assistant European Commission, Mozambique

A Barreto, R Bastos, A Noya National STD and AIDS Control Programme, Mozambique

E Folgosa

National Reference Laboratory Microbiology, Faculty of Medicine, Eduardo Mondlane University, Mozambique

L Fransen

Health, AIDS and Population, DGDEV, European Commission, Belgium

Correspondence to: Dr Brigitte De Hulsters, International Centre for Reproductive Health, University Hospital, De Pintelaan 185 P3, B-9000 Gent, Belgium; bdhulsters@hotmail.com

\section{References}

1 World Bank. World development report. Oxford: Oxford University Press, 1993.

2 United Nations High Commission for Refugees. Mozambique 1993/95 review: towards reintegration. Maputo, Mozambique: UNHCforR, 1995.

3 Bastos R, Folgosa E, Fransen L. Reproductive tract infections in Mozambique: a case study of integrated services. New York: Plenum Press, 1992.

4 Palha de Souza C, Noya A, Barreto A. Resettlement in post-war Mozambique: implications for STD/HIV control. Abstract no ThPE 134, VIII International Conference on AIDS in Africa, Marrakech, Morocco, 1993.

5 Vuylsteke B, Bastos R, Barreto J, et al. High prevalence of STD in a rural area in Mozambique. Genitourin Med 1993:69:427-30.

6 Noya A, Fernandes A. Inquerito de conhecimentos, attitudes e praticas sobre o SIDA em jovens, militares e deslocados de guerra nas provincias de Cabo Delgado e Nampula. Documento do gabinete de epidemiologia, DNS/Ministerio de Saude, 1990.

Accepted for publication 20 September 2002 


\section{A novel research approach in sex on premises venues (SOPV): objective measure of sexual behaviour and low level intrusion to patrons}

Sex on premises venues (SOPV) are commercial venues where men who have sex with men (MSM) meet other MSM for casual, usu ally anonymous, sex. These venues are challenging environments for traditional methods of behavioural research-for example, interviews. An alternative research method adapted from a study with sex workers in Nicaragua may be used in SOPVs. ${ }^{12}$ This study counted the number of used condoms per client as a measure of "safe" sexual behaviour. A pilot study in two parts was conducted at a Melbourne SOPV to determine the feasibility of this approach. The merit of this method was dependent on the consistency of the ratio of used condoms per SOPV patron, and consequently the method's sensitivity to detect behaviour change.

Part 1 of this pilot aimed to establish a system of SOPV waste collection and condom counting. SOPV staff collected venue waste and research staff counted the number of condoms in the waste that were free from condom packaging. Part 2 piloted SOPV staf handing out anonymous, self complete questionnaires to patrons during the time periods when waste was being collected. The questionnaire only asked about anal sex and condom use during the participant's visit at the SOPV.

Part 1 operated on 16 Saturdays and Sundays during the day. An overall ratio of 0.8 condoms per patron was calculated $(95 \% \mathrm{CI}$ : 0.7 to 1.1$)$, and the ratio for each day ranged from 0.3 to 1.6. It was suspected that inconsistent collection of waste on Saturdays and Sundays contributed to the variability of the calculated condom to patron ratio each day. To have the same SOPV staff collecting waste each time and to avoid weekend functions at the SOPV, collection continued on the following nine Wednesday and Thursday evenings. For these evenings an overall ratio of 0.56 condoms per patron was calculated $(95 \%$ CI: 0.4 to 0.7$)$, and the ratio for each day ranged from 0.2 to 1.0

Part 2 of this pilot operated on Wednesday and Thursday evenings of the following 8 weeks. Approximately 180 patrons were given a questionnaire by SOPV staff, of which 76 $(\sim 40 \%)$ completed and returned the questionnaire (mean 43.8 (SD 13.3 years). Forty four participants reported engaging in protected anal sex during their visit to the SOPV (58\%, $95 \%$ CI: $47 \%$ to $69 \%$ ), with a mode of one episode of protected anal sex per visit. Using this proportion of $58 \%$, a ratio of 1.4 condoms per patron engaging in protected anal sex was recalculated for the Saturday and Sunday collections. For all Wednesday and Thursday collections (Part 1 and 2 ) the ratio was 0.9 .

The findings of this pilot study are inconclusive with respect to the value of this research method for behavioural study. Controlling for measurement and selection bias was difficult and resulted in a variable ratio of used condoms to patrons for each collection day. Research projects with more resources should look for greater control of bias, including encouragement of good communication with SOPV staff. However, this pilot study has demonstrated the potential of counting discarded condoms as a measure of safe sex behaviour in SOPVs. Counting condoms is an objective measure that doesn't rely on self reports of behaviour, and condom collection can be conducted with minimal intrusion to patrons visiting the SOPV.

N A Lister, A Smith, A Binger, C K Fairley The University of Melbourne, School of Population Health, 2nd Floor, 723 Swanston Street, Carlton 3053, Victoria, Australia

Correspondence to: Christopher K Fairley, cfairley@unimelb.edu.au

\section{References}

1 Gorter A Miranda E, Smith GD, et al. How many people actually use condoms? An investigation of motel clients in Managua. Soc Sci Med 1993;36:1645-7

2 Egger M, Pauw J, Lopatitzidis A, et al. Promotion of condom use in a high-risk setting in Nicaragua: a randomized controlled trial. Lancet $2000 \cdot 355 \cdot 2101-5$.

Accepted for publication 16 October 2002

\section{NOTICES}

\section{International Herpes Alliance and International Herpes Management Forum}

The International Herpes Alliance has introduced a website (www.herpesalliance.org) from which can be downloaded patient information leaflets. Its sister organisation the International Herpes Management Forum (website: www.IHMF.org) has launched new guidelines on the management of herpesvirus infections in pregnancy at the 9th International Congress on Infectious Disease (ICID) in Buenos Aires.

\section{Pan-American Health} Organization, regional office of the World Health Organization

A catalogue of publications is available online (www.paho.org). The monthly journal of
PAHO, the Pan American Journal of Public Health, is also available (subscriptions: pubsvc@tsp.sheridan.com).

\section{International Congress of the} Society of The Fetus as a Patient

1-4 May 2003, Gran Hotel Sitges, BarcelonaSitges, Spain

Further details: (fax: +34 93418 7832; email bcn2003@iudexeus.uab.es).

\section{Australasian Sexual Health Conference: Tango down South-2003!}

4-7 June 2003, Christchurch Convention Centre, New Zealand

Further details: Dart Associates (tel: +02 9418 9396/97; email: dartconv@mpx.com.au; web site: http://www.acshp.org.au).

\section{CORRECTION}

We would like to apologise for an error that occurred in the paper by McGarrigle et al ( $\mathrm{Sex}$ Transm Infect 2002;78:398-405). In table 2 under the heading "Name and custodian" the following affiliations should have appeared Row one: London School of Hygiene and Tropical Medicine, National Centre for Social Research, and Royal Free \& University College Medical School. Row six: City University and Department of Primary Care and Population Sciences and Royal Free Centre for HIV Medicine, Royal Free \& University Medical College. Row seven: Study on HIV testing Royal Free Hampstead NHS Trust Hospital and Department of Primary Care and Population Sciences and Royal Free Centre for HIV Medicine, Royal Free \& University College Medical School.

\section{EDITORS' NOTICE}

\section{Inadvertent failure to disclose an interest}

Podophyllin office therapy against condyloma should be abandoned. Von Krogh et al (Sex Transm Inf 2001;77:409-12). The author Dr G Von Krogh inadvertently failed to disclose that he had received consultancy fees or reimbursement of expenses to attend educational meetings relating to anogenital papilloma virus infection from the following companies: 3M, Perstorp, Stiefel, Oclassen, and MSD. In addition clinical trials on anogenital HPV infection had been funded within his department by both $3 \mathrm{M}$ and MSD. 